\title{
Synthesis and biological activities of $C$-glycosides of KRN 7000 with novel ceramide residues
}

\author{
Ahmad S. Altiti, Xiaojing Ma, Lixing Zhang, Yi Ban, Richard W. Franck and David R. Mootoo* \\ Department of Chemistry, Hunter College, 695 Park Avenue, New York, \\ NY 10065 and The Graduate Center, CUNY, 365 Fifth Avenue, New \\ York, NY 10016. Department of Microbiology and Immunology, Weill \\ Cornell Medicine. 1300 York Ave, NY, NY. 10065, USA.
}

Keywords: glycolipid, CD1d, NKT, cytokine, C-glycoside

\begin{abstract}
The identification of immunoactive agents for clinical and mechanistic applications is a very active area of research. In this vein, analogues of the potent immunostimulant KRN 7000 with diverse cytokine profiles have attracted considerable attention. Herein, we report on the synthesis and activity for four new $C$-glycosides of KRN 7000, 11-phenylundecanoyl and 11-p-fluorophenylundecanoyl derivatives of $C$-KRN 7000, 2,3-bis-epi- $C$-KRN 7000 and the reverse amide of $C$-KRN 7000. In mice, compared to $C$-KRN 7000, 2,3-bis-epi- $C$-KRN 7000 stimulated higher release of the anti-inflammatory cytokine IL-4 and lower release of the inflammatory cytokines IFN- $\gamma$ and IL-12. The phenyl terminated alkanoyl and reverse amide analogues were inactive. These data suggest that structure activity effects for KRN 7000 are not necessarily additive and their use in the design of new analogues will require an improved understanding of how subtle structural changes impact on cytokine activity.
\end{abstract}

\section{Introduction}

The control of the immune system through the regulation of invariant natural killer T (iNKT) cells by glycolipids is an emerging approach to treating cancer and certain autoimmune disorders. ${ }^{1,2,3,4}$ To treat infections and tumors, a Th1 response is required, while a Th2 response is suited to the control of autoimmune diseases. However, an unbiased Th1/Th2 response is potentially problematic because it may lead to opposing effects against a particular disease condition. ${ }^{5}$ The potency of cytokine release may also present clinical hurdles because too high an upregulation of one pathway may induce iNKT cell hyporesponsiveness or anergy ${ }^{6.78}$ Therefore, a major challenge for glycolipid-based therapies is the identification of glycolipid antigens that 
have well-defined Th-1/Th-2 profiles with measured potencies. The most well-studied glycolipid antigen is $\alpha$-galactosylceramide ( $\alpha$-O-GalCer), also called KRN 7000, which has been tested in several mouse models of disease and in a limited number of human trials. ${ }^{9,10,11,12}$ However, clinical applications of KRN 7000 have been stymied; the consensus of the immunology community is that it is handicapped by its inability to induce a clear Th1/Th2 cytokine bias. In this context $C$ - KRN 7000, the $C$-glycoside analog in which the glycoside oxygen is replaced with a " $\mathrm{CH}_{2}$ ", emerged as a benchmark Th1 biased molecule in mice, inducing high levels of IFN- $\gamma$ and IL-12 with negligible levels of IL-4. Subsequently $C$-KRN 7000 and other $C$ glycoside analogues have been studied in mouse models as a prevention agent for malaria, asthma, arthritis and as a vaccine adjuvant in tuberculosis and influenza. ${ }^{13,14,15,16,17}$

The immunological effects of KRN 7000 are believed to involve its binding to CD1d on APCs, and presentation of the binary complex to TCRs on iNKT cells to form the bioactive ternary complex. ${ }^{18,19,20}$ This assemblage stimulates the production of cytokines. Against this backdrop, we were interested in the new $C$-glycosides 7-10. The activity of these new analogues together with X-ray data for known glycolipids may illuminate the molecular basis for cytokine regulation. $^{21,22,23}$ The 11-phenyl- and 11-p-fluorophenyl- undecanoic derivatives $\mathbf{7}$ and $\mathbf{8}$ are interesting as the analogous $O$-glycosides are reported to show much higher Th-1 bias in against both mice and human iNKT cells compared to their hexacosanoic acid derivatives. ${ }^{24,25,26}$ Similarly, the nuanced cytokine profiles of C2-4 diastereomers of KRN 7000 and C-KRN 7000 relative to analogues with the natural stereochemistry, in particular the high Th-1 bias of 4-epiC-KRN7000, inspired 9..$^{15,1727}$ The reverse amide $\mathbf{1 0}$ is a probe for the binding of the amide residue. $^{28,29,30,31,32}$ 

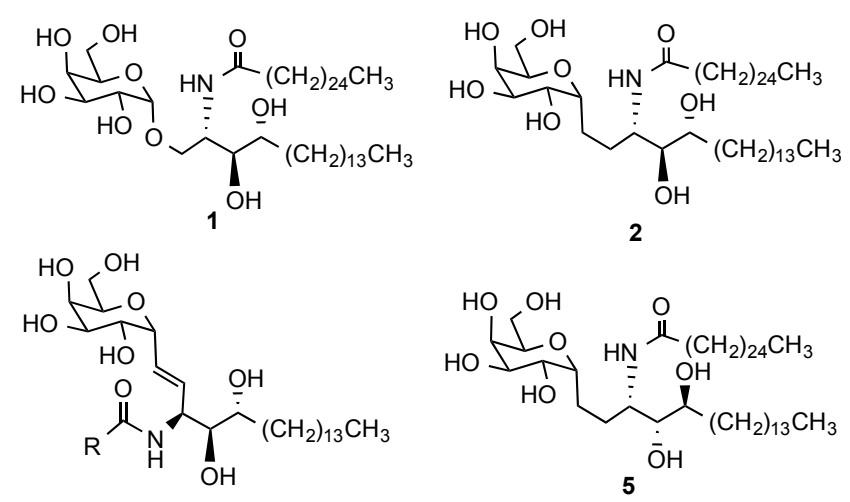

$3 \mathrm{R}=\left(\mathrm{CH}_{2}\right)_{27} \mathrm{CH}_{3}$
$4 \mathrm{X}=\left(\mathrm{CH}_{2}\right)_{7} \mathrm{C}_{6} \mathrm{H}_{5}$
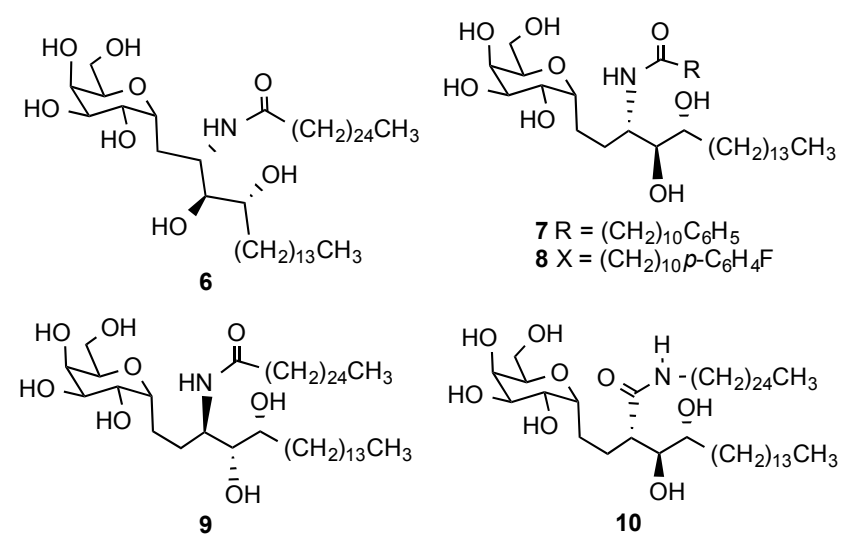

Figure 1. Known and new analogues of KRN7000

\section{Results and Discussion}

Synthesis. The phenyl terminated alkanoyl derivatives $\mathbf{7}$ and $\mathbf{8}$ were prepared from $\alpha$ - $C$-glycoside 11. The latter originated from $\alpha$-C-allyl tetra-O-benzylgalactoside as previously described, and showed no evidence of the $\beta$ - $C$-glycoside (Scheme 1$).{ }^{33}$ Thus, transfer hydrogenation conditions on 11 was used for removal of the benzyl protecting groups because of the difficulty in cleavage of the N-benzyl under standard hydrogenolysis conditions. ${ }^{34}$ The crude product from this reaction was then treated with the $p$-nitrophenyl ester of the requisite fatty acid to give $\mathbf{7}$ and $\mathbf{8}$ in 83 and 95\% yield respectively, over two steps. These materials were purified by silica gel chromatography with a gradient elution of 5-15\% methanol in chloroform, as previously 
described for related analogues of KRN $7000 .{ }^{16,17,32,35,36,37}$ The final compounds and their peracetylated derivatives were characterized by NMR and HRMS analysis. The synthesis of 2,3bisepimer of $C$-KRN 7000, 9 and the reverse amide of C-KRN 7000, 10 has been reported as part of our earlier studies on $C$-glycosides. ${ }^{38}$

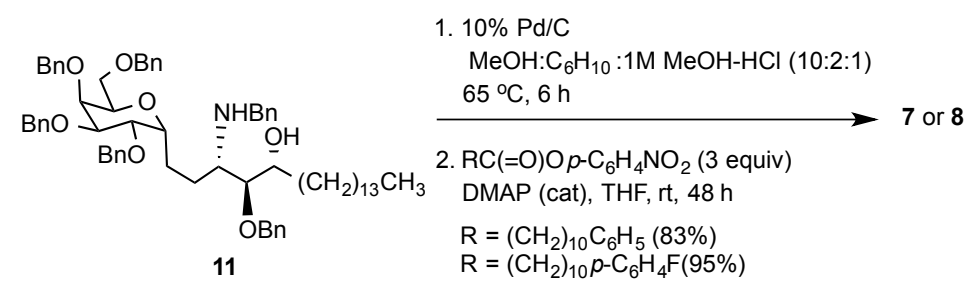

\section{Scheme 1. Synthesis of 11-phenylundecanoyl amides 7 and 8}

Biological evaluation. The cytokine production levels induced by $\mathbf{7}$ - $\mathbf{1 0}$ were determined as reported. ${ }^{13,14} C$-KRN 70002 and $\mathbf{3}$ were used as controls. ${ }^{14}$ Test compounds were administered to C57BL/6 mice by intraperitoneal injection. Sera were collected at $0,6,12$ and $24 \mathrm{~h}$ after treatment for ELISA analysis of IFN- $\gamma$, IL-12 and IL-4 concentrations. In agreement with published data, 2 and $\mathbf{3}$ induced relatively high levels of Th1 cytokines IFN- $\gamma$ and IL-12 compared to the Th2 cytokine IL-4. The $C$-KRN 7000 diastereomer 9 also induced higher IFN- $\gamma$ than IL-4, but the level of IFN- $\gamma$ production was lower, and that of IL-4 higher, compared to 2 and 3. Compared to $\mathbf{2}$ and $\mathbf{3}$, compound $\mathbf{9}$ induced a higher level of IL-4 than IL-12. The phenyl terminated alkanoyl and the reverse amide analogues 7, 8 and $\mathbf{1 0}$ did not induce any noticeable production of cytokines. (Figure 2).

The lower potency of IFN- $\gamma$ induced by $\mathbf{9}$ compared to $\mathbf{2}$, together with the disparate activities of other diastereomers of $\mathbf{2}$, and analogous $O$-glycosides, suggest that cytokine activity is particularly sensitive to structural changes in the polar region of the ceramide residue. ${ }^{15,17,27}$ This is consistent with the fact that this region is intimately engaged in the ternary complex, and the 
notion that binding in the ternary complex impacts on cytokine potency and ratio..$^{21,22,23,39}$ That compounds $\mathbf{7}$ and $\mathbf{8}$, the phenyl terminated undecanoyl analogues of $\mathbf{2}$ were inactive, whereas $\mathbf{2}$ was, is also noteworthy. In the $O$-glycoside series these phenyl terminated alkanoyl modifications have been shown to markedly increase the potency of cytokine production relative to their hexacosanoyl derivatives. ${ }^{24,25,26}$ Therefore, given the remote positions of these two loci, it was surprising that these fatty acid modifications deactivated rather than activated, the $C$ glycoside 2. This said, a similar loss in activity in a murine assay was observed when the hexacosanoic acid residue in $C$-glycosides 3 was replaced with an 8-phenyloctanoyl chain (cf $\mathbf{4}$ ), although against human iNKT cells, the expected increase in cytokine release was observed. ${ }^{14}$ Thus the cytokine activating effect of phenyl terminated alkanoyl chains may not be general for different classes of lipids, and for mice and human assays. Since the amide carbonyl in KRN 7000 is not believed to interact directly in the ternary complex, the loss of activity for the inverse amide 10 supports the notion that the amide $\mathrm{NH}$ acts as a $\mathrm{H}$-bond donor and a precise location of the amide bond is critical for activity. ${ }^{40}$ In light of the observation that ester derivatives of KRN 7000 still retain some activity, the complete loss in activity of $\mathbf{1 0}$, suggests that the carbonyl residue may also be an important receptor contact. However, given our limited data, and the multi-factorial nature of cytokine stimulation, further speculation on the molecular basis for the observations on $\mathbf{7}$ - $\mathbf{1 0}$ is premature. 

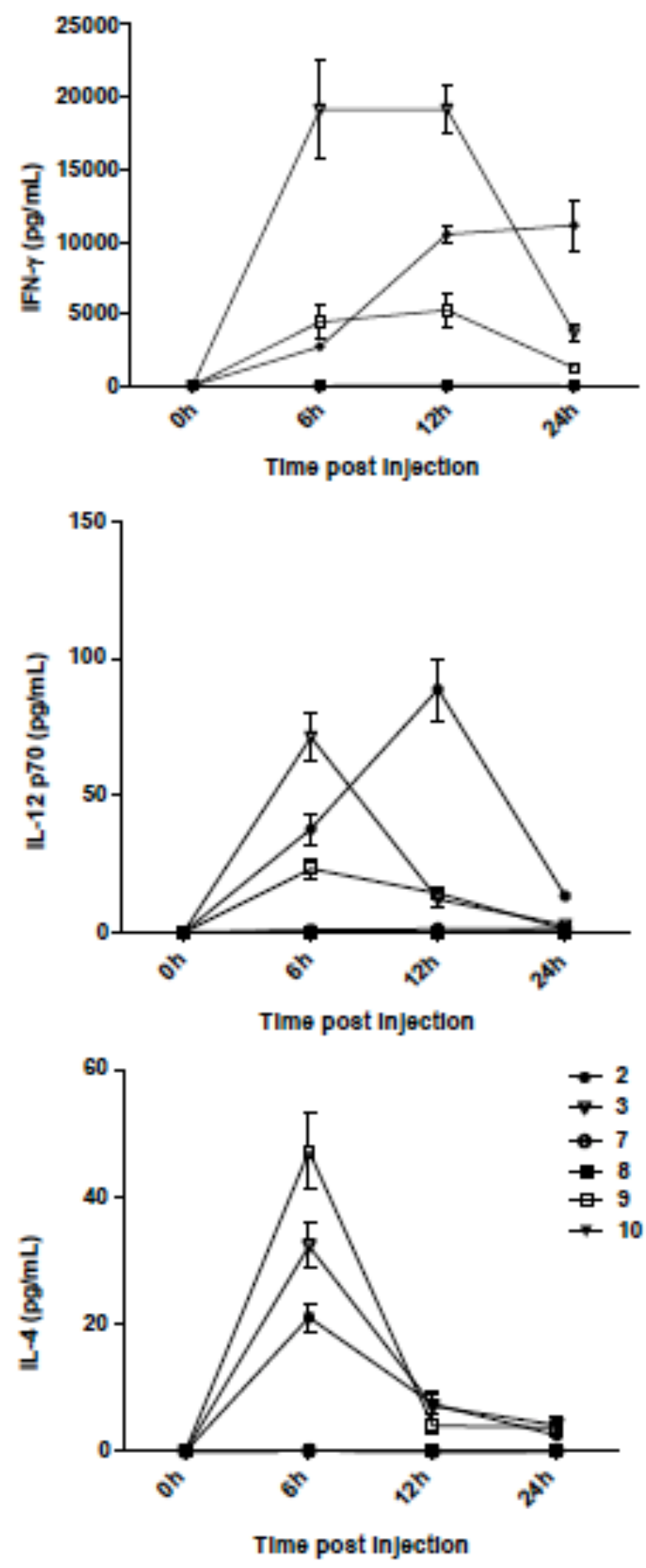

Figure 2. Serum cytokine concentrations for mice administered with glycolipids. Representative data from one of three experiments. Error bars represent the standard deviation for triplicate wells. $\mathrm{P}<0.05$ as determined by the Student t-test with $\mathbf{2}$ and DMSO as controls. 


\section{Conclusion}

Four new $C$-glycosides of KRN 7000, 11-phenylundecanoyl and 11-p-fluorophenylundecanoyl derivatives of C-KRN7000, 2,3-bis-epi-C-KRN 7000 and the reverse amide of C-KRN 7000 were synthesized and their cytokine activity evaluated. In mice, compared to $C$-KRN 7000, 2,3bis-epi-C-KRN7000 stimulated higher release of the anti-inflammatory cytokine IL-4 and lower release of the inflammatory cytokines IFN- $\gamma$ and IL-12. The phenyl terminated alkanoyl and reverse amide analogues analogues were inactive. The activity of the 2,3-bis-epi-C-KRN 7000 was in line with the cytokine profile exhibited by diastereomeric $O$ - and $C$-glycosides. The loss of activity in the reverse amide is consistent with structure activity hypotheses for the amide residue. However, given the high cytokine potency associated with phenyl terminated alkanoyl analogues of KRN 7000, the complete loss in activity for the 11-phenylundecanoyl $C$-glycosides was surprising. This unexpected loss reinforces the emerging idea that activity enhancements by changes at different loci of the parent $O$-glycoside are not necessarily additive. Thus the use of SAR data to design new analogs may require an improved understanding of how subtle structural changes impact on cytokine activity.

\section{Experimental Section}

\subsection{General}

Unless otherwise stated, all reactions were carried out under a nitrogen atmosphere in oven-dried glassware using standard syringe and septa technique. NMR spectra were obtained on 500 or 600 $\mathrm{MHz}$ instruments. Chemical shifts are relative to the deuterated solvent peak or the tetramethylsilane (TMS) peak at $(\delta 0.00)$ and are in parts per million $(\mathrm{ppm})$. Assignments for selected nuclei were determined from ' $\mathrm{H}$ COSY experiments. Optical rotations $[\alpha]_{\mathrm{D}}$ are given in 
units of $10^{-1} \mathrm{degcm}^{2} \mathrm{~g}$ at $589 \mathrm{~nm}$ (sodium D-line). Thin layer chromatography (TLC) was done on $0.25 \mathrm{~mm}$ thick pre-coated silica gel HF254 aluminum sheets. Chromatograms were observed under UV (short and long wavelength) light, and/or were visualized by heating plates that were dipped in a solution of ammonium (VI) molybdate tetrahydrate (12.5 g) and cerium (IV) sulfate tetrahydrate $(5.0 \mathrm{~g})$ in $10 \%$ aqueous sulphuric acid $(500 \mathrm{~mL})$. Flash column chromatography (FCC) was performed using silica gel 60 (230-400 mesh) and employed a stepwise solvent polarity gradient, correlated with TLC mobility. Hexanes used for FCC had a boiling point in the $40-60{ }^{\circ} \mathrm{C}$ range.

\section{2 $\quad$ C-KRN 7000 - 11-phenylundecanoyl amide 7}

A mixture of $11(85 \mathrm{mg}, 0.083 \mathrm{mmol}), 10 \% \mathrm{Pd} / \mathrm{C}(85 \mathrm{mg})$, cylclohexene $(0.4 \mathrm{~mL})$ and $1 \mathrm{~N} \mathrm{HCl}$ $(0.1 \mathrm{~mL})$ in $\mathrm{MeOH}(2 \mathrm{~mL})$, was heated at reflux for $6 \mathrm{~h}$. The mixture was then cooled to $\mathrm{rt}$, filtered over a pad of Celite and basic resin, and concentrated in vacuo to give a white solid (45 $\mathrm{mg})$, which was used directly in the next step. A portion of this material $(10 \mathrm{mg}, 0.021 \mathrm{mmol})$ was taken up in THF $(1 \mathrm{~mL})$ and treated with $p$-nitrophenyl 1-phenylundecanoate (24 mg, 0.063 mmol) and DMAP $(0.5 \mathrm{mg})$. The mixture was stirred at $\mathrm{rt}$ for $48 \mathrm{~h}$, then concentrated in vacuo. The residue was taken up in $\mathrm{MeOH}(0.5 \mathrm{~mL})$ and treated with $1 \mathrm{M} \mathrm{NaOMe}$ in $\mathrm{MeOH}(0.5 \mathrm{~mL})$ for $30 \mathrm{~min}$. The solution was adjusted to $\mathrm{pH} 7$ with Dowex 50WX8 resin, the mixture filtered over a Celite pad and the filtrate concentrated in vacuo. FCC of the residue using a gradient elution with $5-15 \% \mathrm{MeOH}_{-} \mathrm{CHCl}_{3}$, afforded 7 as a white solid (10 $\mathrm{mg}$, ca $83 \%$ over 2 steps): $\mathrm{R}_{f}=$ $0.24\left(15 \% \mathrm{MeOH}-\mathrm{CHCl}_{3}\right) ;{ }^{1} \mathrm{H} \mathrm{NMR}\left(500 \mathrm{MHz}, \mathrm{C}_{5} \mathrm{D}_{5} \mathrm{~N}\right) \delta 8.42(\mathrm{~d}, J=9.0 \mathrm{~Hz}, 1 \mathrm{H}, \mathrm{NH}), 7.38-$ $7.23(\mathrm{~m}, 5 \mathrm{H}, \mathrm{ArH}), 6.80-5.40(\mathrm{bm}, 6 \mathrm{H}, \mathrm{OH}), 5.14(\mathrm{~m}, 1 \mathrm{H}, \mathrm{H} 2), 4.74(\mathrm{dd}, J=8.9,5.5 \mathrm{~Hz}, 1 \mathrm{H}$, H3'), 4.53 (m, 3H, H1', H2'/4', H6'), 4.38 (dd, J = 11.2, 4.6 Hz, 1H, H6'), 4.25 (m, 4H, H3, H4, 
H2'/4', H5'), 2.72 (m, 1H, H1), 2.58 (m, 3H, Ha, $\left.\mathrm{CH}_{2}-11^{\prime \prime}\right), 2.45$ (m, 2H, $\mathrm{CH}_{2}-2$ '), 2.31 (m, 2H, Ha, H5), 2.22 (m, 1H, H1), 1.93 (m, 2H, H5, H6), 1.85 (m, 2H, $\mathrm{CH}_{2}-3$ ”), 1.70 (m, 1H, H6), 1.58 (m, 2H, $\left.\mathrm{CH}_{2}-10 ”\right), 1.40-1.10(\mathrm{~m}, 34 \mathrm{H}), 0.87\left(\mathrm{t}, J=6.8 \mathrm{~Hz}, 3 \mathrm{H}, \mathrm{CH}_{3}\right) .{ }^{13} \mathrm{C} \mathrm{NMR}(125 \mathrm{MHz}$,

$\left.\mathrm{C}_{5} \mathrm{D}_{5} \mathrm{~N}\right) \delta 173.9,143.7,129.3,129.2,126.5,79.0,77.5,74.2,73.1,72.7,71.1,70.9,63.2,53.1$, $37.4,36.6,34.9,32.6,32.3,30.8,30.7,30.5,30.4,30.3,30.2,30.1,30.0,27.1,27.0,26.9,23.4$, 23.1, 14.7. HRMS (ESI, $\mathrm{MNa}^{+}$) $m / z$ calc for $\mathrm{C}_{42} \mathrm{H}_{75} \mathrm{NO}_{8} \mathrm{Na} 744.5385$, found 744.5388

\subsection{Hexa- $O$-acetyl- $C$-KRN 7000 -11-phenylundecanoyl amide 7-OAc}

Acetic anhydride $(0.05 \mathrm{~mL})$ was added to a solution of $7(10 \mathrm{mg}, 0.014 \mathrm{mmol})$ in a mixture of EtOAc $(1 \mathrm{~mL})$ and pyridine $(0.05 \mathrm{~mL})$. The reaction was stirred at $\mathrm{rt}$ for $16 \mathrm{~h}$, at which time the volatiles were removed in vacuo. FCC of the residue afforded 7-OAc $(10 \mathrm{mg}, 75 \%):{ }^{1} \mathrm{H}$ NMR $\left(500 \mathrm{MHz}, \mathrm{CDCl}_{3}\right) \delta$ 7.26-7.13 (m, 5H, ArH), 5.71 (d, J=9.7 Hz, 1H, NH), 5.38 (bs, 1H, H4'), 5.15 (m, 2H, H2', 3’), 4.90 (m, 2H, H3, 4), 4.30 (dd, $J=9.0,13.0 \mathrm{~Hz}, 1 \mathrm{H}, \mathrm{H6}$ '), 4.17 (m, 1H, H2), 4.06 (m, 1H, H1'), 4.02 (m, 2H, H5', 6'), 2.57 (t, J= $\left.7.7 \mathrm{~Hz}, 2 \mathrm{H}, \mathrm{CH}_{2}-11^{\prime \prime}\right), 2.15$ (t, $J=7.7$ Hz, 2H, $\mathrm{CH}_{2}-2$ "), 2.09 (s, 3H, Ac), 2.08 (s, 3H, Ac), 2.04 (s, 6H, Ac), 2.03 (s, 3H, Ac), 2.01 (s, 3H, Ac), $1.63(\mathrm{~m}, 1 \mathrm{H}), 1.56(\mathrm{~m}, 8 \mathrm{H}), 1.40(\mathrm{~m}, 1 \mathrm{H}), 1.22(\mathrm{~m}, 36 \mathrm{H}), 0.86\left(\mathrm{t}, J=6.8 \mathrm{~Hz}, 3 \mathrm{H}, \mathrm{CH}_{3}\right)$. ${ }^{13} \mathrm{CNMR}\left(125 \mathrm{MHz}, \mathrm{CDCl}_{3}\right) \delta 173.1,171.3,170.8,170.2,170.1,170.0$ (two peaks), 143.1, 128.6, 128.4, 125.8, 75.8, 72.9, 72.0, 68.7 (two peaks), 68.0, 67.6, 61.3, 48.7, 37.1, 36.2, 32.2, $31.8,29.9,29.8,29.7,29.6,29.1,27.0,26.0,25.7,22.9,22.7,21.3,21.1,21.0,20.9,14.3$. HRMS (ESI, $\mathrm{MNa}^{+}$) $m / z$ calc for $\mathrm{C}_{54} \mathrm{H}_{87} \mathrm{NO}_{14} \mathrm{Na} 996.6019$, found 996.6002.

\subsection{C-KRN 7000-11-p-fluorophenyl-undecanoyl amide 8}

A portion of the material from the hydrogenolysis of $11(10 \mathrm{mg}, 0.021 \mathrm{mmol})$ was taken up in 
THF $(1 \mathrm{~mL})$ and treated with $p$-nitrophenyl 4-fluorophenylundecanoate ${ }^{16}(25 \mathrm{mg}, 0.063 \mathrm{mmol})$ and DMAP $(0.5 \mathrm{mg})$. The reaction was processed as described for the preparation of 7. FCC of the residue afforded 8 as a white solid (12 $\mathrm{mg}$, ca $88 \%$ over 2 steps): $\mathrm{R}_{f}=0.26(15 \% \mathrm{MeOH}-$ $\left.\mathrm{CHCl}_{3}\right) ;{ }^{1} \mathrm{H} \mathrm{NMR}\left(500 \mathrm{MHz}, \mathrm{C}_{5} \mathrm{D}_{5} \mathrm{~N}\right) \delta 8.46(\mathrm{~d}, J=9.0 \mathrm{~Hz}, 1 \mathrm{H}, \mathrm{NH}), 7.20-7.11(\mathrm{~m}, 4 \mathrm{H}, \mathrm{ArH})$, 5.15 (m, 1H, H2), 4.74 (dd, $J=8.9,5.5$ Hz, 1H, H3'), 4.52 (m, 3H, H1', H2'/4', H6'), 4.37 (dd, $J$ = 11.2, 4.6 Hz, 1H, H6'), 4.24 (m, 4H, H2'/4', H5', H3, H4), $2.73(\mathrm{~m}, 1 \mathrm{H}, \mathrm{H} 1), 2.60$ (m, 1H, Ha), 2.51 (t, $J=7.9 \mathrm{~Hz}, 2 \mathrm{H}, \mathrm{CH}_{2}-11$ ”), 2.48 (m, 2H, $\mathrm{CH}_{2}-2$ "), 2.36 (m, 2H, Ha, H5), 2.24 (m, 1H, H1), 1.95 (m, 2H, H5, H6), 1.86 (m, 2H, $\mathrm{CH}_{2}-3$ "), 1.70 (m, 1H, H6), 1.50 (m, 2H, $\left.\mathrm{CH}_{2}-10 "\right)$ $1.45-1.10(\mathrm{~m}, 34 \mathrm{H}), 0.88\left(\mathrm{t}, J=6.7 \mathrm{~Hz}, 3 \mathrm{H}, \mathrm{CH}_{3}\right) .{ }^{13} \mathrm{C} \mathrm{NMR}\left(125 \mathrm{MHz}, \mathrm{C}_{5} \mathrm{D}_{5} \mathrm{~N}\right) \delta 173.4,161.6$ $\left(\mathrm{d}, J_{C-F}=240.5 \mathrm{~Hz}\right), 139.1\left(\mathrm{~d}, J_{C-F}=2.8 \mathrm{~Hz}\right), 130.4\left(\mathrm{~d}, J_{C-F}=7.4 \mathrm{~Hz}\right), 115.3\left(\mathrm{~d}, J_{C-F}=20.8 \mathrm{~Hz}\right)$, $78.5,77.1,73.8,73.1,72.7,72.2,70.6,70.4,62.8,52.7,37.0,35.2,34.5,32.2,30.9,30.4,30.2$, 30.1, 30.0, 29.9, 29.7, 29.6, 29.5, 26.6, 26.5, 23.0, 22.6, 14.3. HRMS (ESI, $\left.\mathrm{MNa}^{+}\right) \mathrm{m} / z$ calc for $\mathrm{C}_{42} \mathrm{H}_{74} \mathrm{FNO}_{8} \mathrm{Na} 762.5291$, found 762.5294 .

\subsection{Hexa- $O$-acetyl- $C$-KRN 7000-11-p-fluorophenylundecanoyl amide 8-OAc}

Compound 8-OAc was prepared from 8, following the procedure used for 7-OAc. For 8-OAc: ${ }^{1} \mathrm{H}$ NMR (500 MHz, $\left.\mathrm{CDCl}_{3}\right) \delta 7.08$ (m, dt, J = 2.0, 6.0 Hz, 2H, ArH), $6.92(\mathrm{t}, \mathrm{J}=6.0,2 \mathrm{H}, \mathrm{ArH})$, 5.69 (d, $J=9.7 \mathrm{~Hz}, 1 \mathrm{H}, \mathrm{NH}), 5.38$ (bs, 1H, H4'), 5.14 (m, 2H, H2', 3'), 4.89 (m, 2H, H3, 4), 4.30 (dd, $J=9.0,13.0 \mathrm{~Hz}, 1 \mathrm{H}, \mathrm{H6}$ '), 4.17 (m, 1H, H2), 4.06 (m, 1H, H1'), 4.00 (m, 2H, H5', 6'), $2.53\left(\mathrm{t}, J=7.7 \mathrm{~Hz}, 2 \mathrm{H}, \mathrm{CH}_{2}-11\right.$ ”), 2.15 (t, $J=7.7 \mathrm{~Hz}, 2 \mathrm{H}, \mathrm{CH}_{2}-2$ "), 2.08 (s, 3H, Ac), 2.07 (s, 3H, Ac), $2.04(\mathrm{~s}, 6 \mathrm{H}, \mathrm{Ac}), 2.03(\mathrm{~s}, 3 \mathrm{H}, \mathrm{Ac}), 2.01(\mathrm{~s}, 3 \mathrm{H}, \mathrm{Ac}), 1.74(\mathrm{~m}, 1 \mathrm{H}), 1.56(\mathrm{~m}, 8 \mathrm{H}), 1.40(\mathrm{~m}$, $1 \mathrm{H}), 1.22(\mathrm{~m}, 36 \mathrm{H}), 0.85\left(\mathrm{t}, J=6.8 \mathrm{~Hz}, 3 \mathrm{H}, \mathrm{CH}_{3}\right) .{ }^{13} \mathrm{CNMR}\left(125 \mathrm{MHz}, \mathrm{CDCl}_{3}\right) \delta 173.1,171.3$, 170.8 (two peaks), 170.2, 170.1, 170.0, $161.6\left(\mathrm{~d}, J_{C-F}=240.5 \mathrm{~Hz}\right), 139.1\left(\mathrm{~d}, J_{C-F}=2.8 \mathrm{~Hz}\right)$, 
$129.9\left(\mathrm{~d}, J_{C-F}=7.4 \mathrm{~Hz}\right), 115.1\left(\mathrm{~d}, J_{C-F}=20.8 \mathrm{~Hz}\right), 75.7,72.9,72.0,68.8,68.7,68.0,67.5,61.3$, $48.7,37.1,35.3,32.2,31.8,29.9,29.8,29.7,29.6,29.4,29.1,27.0,26.0,25.7,22.9,22.7,21.3$, 21.1, 21.0, 20.9, 14.3. HRMS (ESI, $\mathrm{MNa}^{+}$) $\mathrm{m} / z$ calc for $\mathrm{C}_{54} \mathrm{H}_{86} \mathrm{FNO}_{14} \mathrm{Na} 1014.5925$, found 1014.5909.

\subsection{Determination of serum cytokine concentration}

6-8-week-old female C57BL/6 mice were purchased from the Jackson Laboratory and were maintained in animal facility of Weill Cornell Medical College. The cytokine production levels induced by glycolipids were determined as reported. ${ }^{13,14}$ The test compounds were taken up in DMSO $(1 \mathrm{mg} / \mathrm{mL})$ and warmed to $50-55{ }^{\circ} \mathrm{C}$ and sonicated. For each test compound $4 \mu \mathrm{L}$ of the stock solution was diluted in $100 \mu \mathrm{L}$ of $10 \mathrm{mM}$ PBS buffer, warmed to $50-55{ }^{\circ} \mathrm{C}$, sonicated again, and administered to C57BL/6 mice by intraperitoneal injection. Sera were collected at 0 , 6, 12 and $24 \mathrm{~h}$ after glycolipid treatment for ELISA analysis of IFN- $\gamma$, IL-12 and IL-4 concentrations. IFN- $\gamma$ production in serum was tested using enzyme-linked immunosorbent assay (ELISA, eBioscience). Serum concentrations of IL-12(p70) and IL-4 were measured using ELISA (BioLegend). Each compound was administered to two or three different mice in three independent experiments and the serum from each mice was tested in triplicate. Representative data for one of the three experiments are shown. The data were expressed as the mean \pm standard deviation (SD) of triplicate wells. A $p$-value $<0.05$ was determined by the Student t-test with DMSO and 2 as controls.

\section{Acknowledgment}

This work was supported by the National Science Foundation (CHE-1301330). A Research 
Centers in Minority Institutions Program grant from the National Institute of Health Disparities (MD007599) of the National Institutes of Health (NIH), which supports the infrastructure at Hunter College, and a Clinical Translational Science Center award (TR000457) from the NIH are also acknowledged.

\section{References}

1. Van Kaer, L.; Parekh, V. V.; Wu, L.Immunotherapy 2011, 3, 59-75.

2. Shissler, S. C.; Bollino, D. R.; Tiper, I. V.; Bates, J. P.; Derakhshandeh, R.; Webb, T. J.

3. Birkholz, A. M.; Howell, A. R.; Kronenberg, M. J. Biol. Chem. 2015, 290, 20746-20746.

4. Carreño, L. J.; Saavedra-Ávila, N. A.; Porcelli, S. A. Clin. Trans. Immun. 2016, 5, e69

5. O’Garra, A. Immunity 1998, 8, $275-283$.

6. Uldrich, A.P.; Crowe, N. Y.; Kyparissoudis, K.; Pellicci, D. G.; Zhan, Y.; Lew, A. M.;

Bouillet, P.; Strasser, A.; Smyth, M. J.; Godfrey, D. I. J. Immunol. 2005, 175, 3092-3101.

7. Parekh, V. V.; Wilson, M. T.; Olivares-Villagómez, D.; Singh, A. K.; Wu, L.; Wang, C.-R.;

Joyce, S.; Van Kaer. L. J. Clin. Invest. 2005, 115, 2572-2583.

8. Wingender, G.; Birkholz, A. M.; Sag, D.; Farber, E.; Chitale, S.; Howell, A. R.; Kronenberg, M. J. Immun. 2015, 195, 3838-3848.

9. Banchet-Cadeddu, A.; Hénon, E.; Dauchez, M.; Renault, J.-H.; Monneaux, F.; Haudrechy, A. Org. Biomol. Chem. 2011, 9, 3080-3104.

10. Tashiro, T. Biosci. Biotechnol. Biochem. 2012, 76, 1055-1067.

11. Laurent, X.; Bertin, B.; Renault, N.; Farce, A.; Speca, S.; Milhomme, O.; Millet, R.;

Desreumaux, P.; Hénon, E.; Chavatte, P. J. Med. Chem. 2014, 57, 5489-5508.

12. Marzabadi, C. H.; Franck, R. W. Chem. Eur. J. 2016, 22, 1-16.

13. Schmieg, J.; Yang, G.; Franck, R. W.; Tsuji, M. J. Exp. Med. 2003, 198, 1631-1641.

14. (a) Li, X.; Chen, G.; Garcia-Navarro, R.; Franck, R.; Tsuji, M. Immunol. 2008, 127, 216-225.

(b) Li, X.; Shiratsuchi, Chen, G.; Dellabona, P.; Casorati, G.; Franck, R.; Tsuji, M. J. Immunol. 2009, 183, 4415-4421. (c) Franck, R. W. C. R. Chimie 2012, 15, 46-56 and refs 7-12. 
15. Pu, J.; Franck, R. W. Tetrahedron 2008, 64, 8618-8629.

16. (a) Liu, Z.; Courtney, A. N.; Metelitsa, L. S.; Bittman, R. ChemBioChem 2012, 13, 1733-1737. (b) Liu, Z.; Bittman, R. Org. Lett. 2012, 14, 620-623. (c) Liu, Z.; Byun, H.-S.

Bittman, R. Org. Lett., 2010, 12, 2974-2977.

17. Chang, Y.-J.; Hsuan, Y.-C.; Lai, A. C.-Y.; Han, Y.-C.; Hou, D. R. Org. Lett. 2016, 18, 808811.

18. Rossjohn, J.; Pellicci, D. G.; Patel, O.; Gapin, L.; Godfrey, D. I. Nature Rev. Immun. 2012, $12,845-857$.

19. Zajonc, D. M. Immunogenetics 2016, 68, 561-576.

20. Van Kaer, L.; Wu, L.; Joyce, S. Trends Immun. 2016, 37, 738-754.

21. Aspeslagh, S.; Li, Y.; Yu, E. D.; Pauwels, N.; Trappeniers, M.; Girardi, E.; Decruy, T.; Van Beneden, K.; Venken, K.; Drennan, M.; Leybaert, L.; Wang, J.; Franck, R. W.; Van Calenbergh, S.; Zajonc, D. M.; Elewaut, D. EMBO J, 2011, 30, 2294-2305.

22. Patel, O.; Cameron, G.; Pellicci, D. G.; Liu, Z.; Byun, H.-S.; Beddoe, T.; McCluskey, J.;

Franck, R. W.; Castano, A. R.; Harrak, Y.; Llebaria, A.; Bittman, R.; Porcelli, S. A.; Godfrey, D. I.; Rossjohn, J. J. Immunol. 2011, 187, 4705-4713.

23. Rossjohn, J.; Pellicci, D. G.; Patel, O.; Gapin, L.; Godfrey, D. I. Nat. Rev. Immun. 2012, 12, 845-857.

24. Li, X.; Fujio, M.; Imamura, M.; Wu, D.; Vasan, S.; Wong, C.-H.; Ho, D.D.; Tsuji, M. Proc . Natl. Acad.Sci. U.S.A. 2010, 107, 13010-13015.

25. Wu, T.-N.; Lin, K.-H.; Chang, Y.-J.; Huang, J.-R.; Cheng, J.-Y.; Yu, A. L.; Wong, C.-H. Proc. Natl. Acad.Sci. U.S.A. 2011, 108, 17275-17280.

26. Wu, T.-N.; Lin, K.-H.; Wu, Y.-T.; Huang, J.-R.; Hung, J.-T.; Wu, J.-C.; Chen, C.-Y.; Chu, K.-C.; Lin, N.-H.; Yu, A. L.; Wong, C.-H. ACS Chem. Biol. 2016, DOI: 10.1021/acschembio.6b00650.

27. Park, J.-J.; Lee, J. H.; Seo, K.-C..; Bricard, G.; Venkataswamy, M. M.; Porcelli, S. A.; Chung, S.-K. Bioorg. Med. Chem. Lett. 2010, 20, 814-818.

28. Tashiro, T.; Hongo, N.; Nakagawa, R.; Seino, K.; Watarai, H.; Ishii, Y.; Taniguchi, M.; Mori, K. Bioorg. Med. Chem. 2008, 16, 8896-8906. 
29. Shiozaki, M.; Tashiro, T.; Koshino, H.; Nakagawa, R.; Inoue, S.; Shigeura, T.; Watarai, H.; Taniguchi, M.; Mori, K. Carbohydr. Res. 2010, 345, 1663-1684.

30. Banchet-Cadeddu, A.; Martinez, A.; Guillarme, S.; Parietti, V.; Monneaux, F.; Hénon, E.;

Renault, J.-H.; Nuzillard, J.-M.; Haudrechy, A. Bioorg. Med. Chem. Lett. 2011, 21, 2510-2514.

31. Tashiro, T.; Shigeura, T.; Watarai, H.; Taniguchi, M.; Mori, K. Bioorg. Med. Chem. 2012, $20,4540-4548$.

32. Wojno, J.; Jukes, J.-P.; Ghadbane, H.; Shepherd, D.; Besra, G. S.; Cerundolo, V.; Cox, L. R. ACS Chem. Biol. 2012, 7, 847-855.

33. Altiti, A. S.; Mootoo, D. R. Org. Lett. 2014, 16, 1466-1469.

34. Jackson, A. E.; Johnstone, R. A. W. Synthesis 1976, 685-687.

35. Tyznik, A. J.; Farber, E.; Girardi, E.; Birkholz, A.; Li, Y.; Chitale, S.; So, R.; Arora, P.;

Khurana, A.; Wang, J.; Porcelli, S. A.; Zajonc, D. M.; Kronenberg, M.; Howell, A. R. Chem.

Biol. 2011, 18, 1620-1630.

36. Trappeniers, M.; Van Beneden, K.; Decruy, T.; Hillaert, U.; Linclau, B.; Elewaut, D.; Van

Calenbergh, S. J. Am. Chem. Soc. 2008, 130, 16468-16469

37. Fujio, M.; Wu, D.; Garcia-Navarro, R.; Ho, D. D.; Tsuji, M.; Wong, C.-H. J. Am. Chem. Soc. 2006, 128, 9022-9023.

38. Altiti, A. S.; Bachan, S.; Mootoo, D. R. Org. Lett. 2016, 18, 4654-4657.

39. Wu, T.-N.; Lin, K.-H.; Chang, Y.-J.; Huang, J.-R., Cheng, J.-Y.; Yu, A. L.; Wong, C.-H. PNAS 2011, 108, 17275-17280.

40. Hénon, E.; Dauchez, M.; Haudrechy, A.; Banchet, A. Tetrahedron 2008, 64, 9480-9489. 